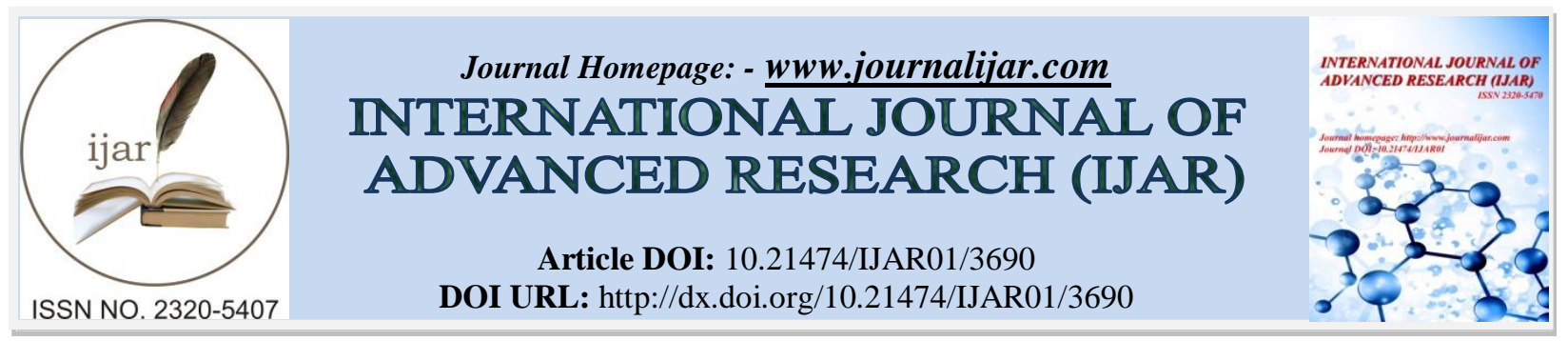

RESEARCH ARTICLE

\title{
LEGAL PROTECTION OF CONVENTIONAL CRIME VICTIM (RESTORATIVE JUSTICE APPROACH).
}

*Taswin Imransyah, Andi Sofyan, Syamsuddin Muchtar and Wiwie Heryani. Graduate School, Hasanuddin University, Indonesia.

\section{Manuscript Info}

Manuscript History

Received: 13 January 2017

Final Accepted: 06 February 2017

Published: March 2017

Key words:-

Criminal Law, Conventional Crime,

Restorative Justice

\begin{abstract}
The rights of crime victims, particularly crime victims or conventional crime in relation to the efforts to achieve restorative justice in the criminal justice system in Indonesia.This research was a socio-legal research, which orientation is focused on legal and non-legal aspects and the operation of law in society. The results of the research indicates that the essence of legal protection for crime victims in the handling of conventional crime in Indonesia is not yet optimal to take attention and gives legal protection to conventional crime victim in achieving fairness, expediency and legal certainty as a legal purpose. Conventional crime victims are an integral part of a legal system, which received less attention in obtaining their rights in the criminal justice system in Indonesia.Legal protection of conventional crime victim in Indonesia has been set in legislations, but it is not optimal because the mostly of legislation is more focused of legal protection to the perpetrators rather than the victims. As a result, the implementation of legal protection for conventional crime victim is not optimal, so it is very important the understanding of community, the victim and also law enforcement officers in the implementation of rules and mechanisms of legal protection against conventional crime victims to get their rights.
\end{abstract}

Copy Right, IJAR, 2017,. All rights reserved.

\section{Introduction:-}

Indonesia is a constitutional state. It is implied in the Preamble of the 1945 Constitution of the Republic of Indonesia which makes specificity that Indonesia intended to protect the entire Indonesian nation and homeland, promote the welfare, educating the nation, and participatesin establish the world order.

Indonesia as a constitutional state provides protection for its citizens by establishes an institution that able to provide justice in the form of free judiciary and impartial. It is based on the argument that every human being from birth bears the rights and obligations that are free and rights, and the holding power of a country should not diminish the meaning of freedom and the humanity rights. A form of protection against the society which should be done by the state is to provide legal protection through a process of judicial in a crime act or called as criminal justice system. 
A party who very wanted the protection in a crime is a crime victim. The victim has important role to be given attention and protection in the criminal justice system. This view is based from the idea that the victim as aggrieved party in a crime, so it should receive the attention and care in order to provide protection against their interests. ${ }^{1}$

In Indonesia, criminal justice system in general put the interests of victims are represented by the public prosecutor, as well as the wider community. Victim losses may be material that can be measured by money, and immaterial includes fear, pain, sadness, surprise psychic and others. Victim protection in the form of compensation for material loss could be charged directly to the perpetrator, but for the restitution of immaterial losses in some countries (if the perpetrators who cannot afford), then the burden to the state. ${ }^{2}$

Provisions regarding the protection of victim crime in the Code of Criminal Procedure are more dominant in the provision regarding restitution, by grouping into 4 (four) forms of victims rights, as follows: ${ }^{3}$

a. Right to control the actions of investigators and public prosecutors, namely right to object to the termination of investigation and/or prosecution in their capacity as an interested third party as stipulated in Article 109 and 140 paragraph (2) Criminal Code Procedure;

b. Victim's rights in their position as a witness, as stipulated in Article 168 of Criminal Code Procedure;

c. Rights for victims' families in case the victim dies, to allow or not the police to conduct a post-mortem or grave digging for autopsy. These rights are stipulated in Article 134 and 136 in the Criminal Code Procedure;

d. Right to demand restitution for losses suffered as causes of criminal acts in their capacity as the suffered party as stipulated in Article 98 and 101 in the Criminal Code Procedure.

The disadvantages of provisions the Criminal Code Procedure in regulating the victim in view of Barda Nawawi Arief, ${ }^{4}$ as follows:

a. There is no legal effort to be conducted by the victim if the victim is not satisfied with a court decision. In contrast with the suspect that can make appeal or judicial review. Victims are represented by the prosecutor as a public prosecutor can only accept the decision.

b. The protection of criminal victims is only stipulated in Chapter XII (Article 98-101) of Criminal Code Procedure, which allows the combination of restitution case to the criminal case.

c. Article 99 of the Criminal Code Procedure asserts that the restitution which can be decided by the judge is only the costs incurred by the suffered party; while the other losses can only be sued through the civil judicial process takes a long time and begins a new procedural.

d. The judge can set a specific requirement that the convicted person within a certain time, which is shorter than the probation, having to restitute the whole or part of losses that caused by the criminal act or in other words that the victim's rights as result of criminal acts only applies when the judge sentenced him/her to probation, while in a crimes that cause huge losses or violent, probation difficult to be given.

e. Cost charged to the perpetrator for restitution is only restricted to the value that is materially.

The disadvantages indicate that the existence and the legal position of crime victims in the criminal justice system is not favorable to crime victims, due to the fundamental problem, namely the victim is only as a witness (complainant or victim). Victims are not included in the elements involved in the criminal justice system;it is not similar to the dependant, the police and the prosecutor.

In principle, the protection of victim has been stipulated in several laws in Indonesia as the embodiment of human rights in the constitution and the rights of victims in the Criminal Code Procedure. The criminal justice system prioritizes the protection of human rights, but if the provisions concerning it be in-depth considered, only the rights of suspects/defendants that many prominent, while the rights of crime victims is very little regulated.

\footnotetext{
${ }^{1}$ Anshari Dimyati.(2013). Kebijakan Perlindungan Hukum Terhadap Saksi dan Korban. Tesis. Universitas Diponegoro : Semarang. p. 3

${ }^{2}$ Lies Sulistiani. (2010). Perlindungan Saksi dan Korban di Indonesia. Press Release No.02/LPSK/PR/II/2010. Lembaga Perlindungan Saksi Republik Indonesia: Jakarta. p. 4

${ }^{3}$ Muhadar et al. (2010). Perlindungan Saksi dan Korban dalam Sistem Peradilan Pidana. Putera Media Nusantara : Surabaya. p. 21

${ }^{4}$ Ibid. Page. 6
} 
Crime victims who are basically a party that suffered in a criminal act, because it has not gained as much protection as provided by the Act to the offender. Crime victims are placed as evidence that provide information, i.e only as a witness, so little possibility for victims to obtain flexibility in fighting their rights. Victims are not given the authority and not actively involved in the process of investigation and trial, so he/she lost the chance to fight their rights and restore their condition as result of a crime. The condition raises a tendency that the right of victim is not protected when the offenders have been sentenced to criminal sanctions by the courts, whereas the issue of justice and respect for human rights does not only apply to offenders but also crime victims. Therefore, the authors are interested in conduct further research and study on the rights of crime victims, particularly crime victims or conventional crime in relation to the efforts to achieve restorative justice in the criminal justice system in Indonesia.

\section{Method of Research:-}

This research was a socio-legal research, which orientation is focused on legal and non-legal aspects and the operation of law in society. Law is conceived not only in the normative dimension but also as an empirical phenomenon that can be observed in the context of reality in the community. In other words, this research examines law both in the aspect of law in books and law in action. The main objective of this research was to examine whether a normative rule (postulate) can or cannot be used to solve a legal problem in reality (in concreto). ${ }^{5}$

This study describes a problem in the community, the procedure applicable in the community and situations, attitude, views, ongoing process, effects of a phenomenon, careful measurement of the phenomenon in the community. The author developed the concept, gather facts, but did not test the hypothesis. Fieldwork was conducted by using in-depth interviews to obtain data in the form of views, thoughts and opinions of the informants. Primary data were intended to obtain confirmation as well as complementary research based on the library study.

\section{Conception of Legal Protection:-}

Guilarmo S. Santos ${ }^{6}$ argued that the concept of constitutional State is understood as a condition in a society where the law in a democratic State is determined by the people which are nothing other than the regulation of relationship between the people. Furthermore, Bothink in Ridwan H.R. ${ }^{7}$ argued that the constitutional State is a State where the freedom of power holders is restricted by law. The other view as proposed by Burkens as quoted Attamimi ${ }^{8}$ argued that the constitutional State (rechtsstaat) are simply as the State that put law as the basis of State power and the implementation of the power in all its forms is done under the rule of law. H.W.R. Wade ${ }^{9}$ argues that in a constitutional State, everything must be done according to law;it specifies that the government must be subject to the law, not the law should be subject to the government.

Constitutional State in Munir Fuady's view ${ }^{10}$ is an administration system that is governed by the law applicable and equitable arranged in a constitution, in which all people in the country, both the governed and the governing, should be subject to the same laws, so everyone is treated same and different people are treated differently on the basis of distinctions rational, irrespective of color, race, gender, religion, region and confidence, and the governments' authority is limited by a principle of distribution of power, so that the government does not act arbitrarily and not in violation rights of the people, hence to give the public an appropriate role and its role in a democratic capabilities.

Budiyanto, ${ }^{11}$ the theory of constitutional State is generally divided into 2 (two) types, i.e the theory of formal constitutional State and the theory of material constitutional State.First, the theory of constitutional Statewas pioneered by Immanuel Kant. His theory resulted in a country is passive; it means that the duties of a State is only maintaining order and security in the country, or the country simply as "night watchman", whereas in social and economic affairs, the State should not interfere. Second, the theory of material constitutional State (welfare state)was pioneered by Kranenburg. This theory states that countries other than the duty to foster public order, and it

\footnotetext{
${ }^{5}$ Bambang Sunggono. (1991). Metode Penelitian Hukum. PT RajaGrafindo Persada. Jakarta. p. 91.

${ }^{6}$ As cited in Mushammad Asrun. (2001). Krisis Peradilan Mahkamah Agung di bawah Soeharto.ELSAM. Lemabaga Studi dan Advokasi Masyarakat : Jakarta . Pages. 40-41

${ }^{7}$ Ridwan, H.R. (2007). Hukum Administrasi Negara. PT RajaGrafindo : Jakarta. p. 49

${ }^{8}$ Hamid A. Attamimi. (1990). Peranan Keputusan Presiden RI Dalam Penyelenggaraan Pemerintahan Negara. Dissertation. Graduate School Universitas Indonesia : Jakarta. p. 8

${ }^{9}$ H.W.R Wade. (1970). Administrative Law. Third Edition. Clarendon Prees : Oxford University. Page. 6

${ }^{10}$ Munir Fuady. (2009). Negara Hukum dan Demorasi. Kencana Prenada Group : Jakarta. Page. 3

${ }^{11}$ Budiyanto. (2000). Dasar-dasar Ilmu TataNegara. Erlangga : Jakarta. Page. 50
} 
also responsible for developing and realizing the welfare of people. This theory is widely practiced in developing countries, such as Indonesia. ${ }^{12}$

As definitions above can be said that the definition of a constitutional State is every act of ruler or its people should be based on the law and as well as put the purpose of the constitutional State, which guarantee the rights of its people. One characteristic of the constitutional State is the realization of an effort to protect the people or legal protection.

Protection comes from the word protectthat means put themselves under something to hidden. The protection has the sense of an act, to protect, provide assistance. ${ }^{13}$

According to J.C.T. Simorangkir and Woerjono Sastropranoto, law is an application of restoration justice in the framework of legal protection for victims of conventional crime victim among others by carrying out penal mediation in order to restitute to the conventional crime victims. However, the restitution does not mean that criminal elements were done then be lost. The restitution will only relieve the perpetrators. Therefore, the concept of restorative justice cannot be implemented purely without a retributive justice, meaning that the restitution to the victims did not causes the offender was not convicted. The development of sentencing is currently in restorative justice models with not negate retributive justice model called the balance perspective sentenced is a balance between the offender's interests, the victim and the community ${ }^{14}$ are regulations that are forcing, which determine human behavior in a community environment created by the agency official.R. Soeroso ${ }^{15}$ argued that the law is a set of rules made by the authorities with the aim to arrange the social life that have a characteristic to commanding and forbidding, and force by impose sanctions for those who break them.

Mochtar Kusumaatmadja ${ }^{16}$ argued that the definition of law should not only look at the law as a set of rules and principles that govern human life in society, but should also include institutions and processes necessary to realize law in reality.

Legal protection is a protection that given to the subject of law in the form of legal instruments preventive and repressive, written and unwritten. In other words, legal protection as a description of the legal function i.e a concept in which law can provide a justice, order, certainty, usefulness and peace. ${ }^{17}$

\section{Facility, Principles and Form of Legal Protection:-}

The term of legal protection for the people is a term that does not include "toward the government" or the action of government. The reason as stated by Philip M. Hadjon ${ }^{18}$ that:

a. The term of peoplealready implies a sense as opposed to the term of government. The term of people is essentially means the governed, (geregeerde). Thus,such term is more specific than the other terms in foreign languages such as folks, people.

b. In essence, the term of peoplemeans the governed and not included the term "towards the government" or on the action of government due to the inclusion of the term might create an impression that there is a confrontation between the people who governed by the government as the ruling.

Philip Hadjan ${ }^{19}$ in his view that puts the legal protection as anything that enabling a person can do and defend their rights as determined by law and its relation to the action of government as a central point of the Philips M. Hadjon, suggests that there are 2 (two) types of legal protection for the people,namely:

a) Preventive legal protection

\footnotetext{
${ }^{12}$ Ibid. Page. 51

${ }^{13}$ Poerwadarminta. Kamus Bahasa Indonesia. Balai Pustaka : Jakarta. Page. 540

${ }^{14}$ J.C.T. Simorangkir and Woerjono Sastropranoto.(1959). Hukum Indonesia. Gunung Agung: Jakarta. Page. 32

${ }^{15}$ Soeroso. (2006). Pengantar Ilmu Hukum. Sinar grafika : Jakarta. Page. 120

${ }^{16}$ Mochtar Kusumaatmadja. (2003). Pengantar Hukum Indonesia. PT. Alumni : Bandung. Page. 65

${ }^{17}$ ibid

${ }_{18 P h i l i p u s}$ M. Hadjon. $\left({ }^{1987}\right)$. Perlindungan Hukum Bagi Rakyat Indonesia Sebuah Study Prinsip-prinsipnya, Penanganannya oleh Pengadilan dalam Lingkungan Peradilan Umum dan Pembentukan Peradilan Administrasi Negara, PT. Bina Ilmu : Surabaya. ${ }^{\mathrm{P}}$ age 1.

19Ibid. 2
} 
Preventive legal protection provides a chance for people to file an objection or opinion before a government decision in definitive. Thus, the preventive protection aimed at preventing disputes.

b) Repressive legal protection

In a repressive legal protection, the people is given a chance to file an objection after the result of a government decision which is definitive in the sense that repressive protection is solve problem. In addition to the preventive and repressive legal protection is also known as the formal and substantive legal protection. Formal legal protection is a legal protection refers to the implementation of the rights and formally adopted in legislation and regulation or agreement. The substantive legal protection is a legal protection refers to the implementation of the rights attached to the substantive law. This means that although it is not applied in the Act but its implementation is attached to the people or their activities. ${ }^{20}$

Victims of Crime:-

\section{Definition of Victims:-}

The word of victim is derived from the Latin word "victim"21 then the sense of victim in the Declaration of Basic Principles of Justice for Victims of Crime and Abuse of Power are person either individually or collectively have suffered losses either physical, mental, emotional and decay (impairment) against their fundamental rights through acts or not, but it is a violation of national criminal law in addition also based on internationally recognized norms relating to the human rights. ${ }^{22}$

Victims in the Indonesian General Dictionary areman or person who suffers an accident because the self-act (desire etc) or others. I.S. Susanto argued that the victim was divided into 2 (two), in both narrow and broad senses. Victims in the narrow sense is the victim of a crime, whereas in a broader sense also includes the victims in various fields such as pollution victims, victims of abuse and so forth.

The victim is a person who suffered a loss in physical, mental or financial as a result of a criminal offense (as aneffect) or a factor the incidence of criminal offense (as a cause). The victim is defined as someone who has suffered a loss as a result of a crime and his/her sense of justice is directly disrupted as a result of his/her experience as a target/criminal target. ${ }^{23}$

Stanciu ${ }^{24}$ argued that in the broad sense a victim is a people who suffer as result of injustice. There are 2 (two) basic characteristic to the victims is suffering and injustice. Victim is not only been seen as a result of illegal acts that the real cause can also create injustice, and then causing victim. The definition is also restricted in the narrow sense as stipulated in the positive law. Indonesian positive law which gives decisive definition of victim, among others, Article 1 number 2 of Witnesses and Victims Protection Acts asserting that the victim was a person who suffered in physical, mental, and/or economic loss as result of a criminal offense.

Declaration of Basic Principles of Justice for Victims of Crime and Abuses of Power defines victims as follows:

"Victims" means persons who, individually, or collectively, have suffered harm, including physical or mental injury, emotional suffering, economic loss or substantial impairment of their fundamental rights, through acts or omissions that are in violation of criminal laws operative within Member States, including those laws proscribing criminal abuse of power. ${ }^{25}$

20Muhammad Tahir Azhary. 1995. Negara Hukum Indonesia Analisis Yuridis Normatif Tentang Unsur-Unsurnya.UI-Press $:{ }^{\text {Jakarta }}$. Page. ${ }^{1 .}$

${ }^{21}$ Ira Dwiati.(2007). Perlindungan Hukum Terhadap Korban Tindak Pidana Perkosaan Dalam Peradilan Pidana.Thesis. Universitas Diponegoro : Semarang. Page. 76

${ }^{22}$ Annex IV Declaration of Bacic Principles of Justice for Victims of Crime and Abuse of Power dalam United Nation Office for Drug Control and crime Prevention, Handbook on Justuce for Victims, Centre of International crime prevention.

${ }^{23}$ Sujoko. (2008). Implementasi Tuntutan Ganti Kerugian Dalam Pasal 98 KUHAP Terhadap Tindak Pidana Pemerkosaan di Wilayah Hukum Semarang. Universitas Diponegoro : Semarang. Page. 1

${ }^{24}$ Ibid. Page. 29

${ }^{25}$ United Nation Declaration of Basic Principles of Justice for Victims of Crime and Abuse of Power 29 November 1985. Available online at: http://www.unrol.org/files/BASICP 4.PDF 


\section{Classification of Crime Victims:-}

Crime victim conception is also formulated in the Declaration of Basic Principles of Justice for Victims of Crime and Abuse of Power, namely:

a. Victims of crime include:

1) Direct victims, i.e victim who directly suffering with criminal offense with the characteristics of victims were either individually or collectively, suffered losses in the form of physical injuries, mental, emotional suffering, loss of income and the suppression of basic human rights, caused by the act or omission that is formulated in the criminal law or caused by the abuse of power.

2) Indirect victims, the emergence of victim as cause of interference of a person in helping the victims directly (direct victims) or participating in the prevention of victim, but he also became a victim of crime, or they depend their life to the direct victims, such as : wife/husband, children and relatives.

b. Victims of abuse of power, the victim is a person who individually or collectively suffered harm, including physical or mental injury, emotional suffering, economic loss or the suppression of the basic human rights, through acts or omissions that do not constitute a violation of National Criminal Act but internationally recognized norms relating to human rights.

Sellin and Wolf made a classification of victims into 5 (five) categories, namely: ${ }^{26}$

1) Primary victimization, i.e individual victim. So,their victim is individual or group.

2) Secondary victimization, in which the victim is a group as a legal entity.

3) Mutual victimization occurs because the attitude or behavior of victims who agree to crimes against him/her.

4) Tertiary victimization victims arising from the implementation of the social order.

5) No victimization, here it does not mean there is no victim, but the victims were not immediately known.

Steven Schafer, in relation to the role of the victim suggested several types of victim in relation to the accountability, namely: $:^{27}$

1) Unrelated victims, are those who do not have any relationship with the perpetrator unless the offender who has committed a crime against him/her. In this type of responsibility lies fully in the hands of the perpetrators.

2) Provocative victims are those who are doing something against the perpetrators and consequently they become victims. Victims in this case were the main perpetrators. In this type of responsibility lies with the two parties that is victim and perpetrator.

3) Precipitative victims, the behavior of victims who unwittingly encourage perpetrator to do evil. In this type of responsibility lies with the perpetrator.

4) Biologically weak victims are those who have certain physical and mental shape that encourages people to do evil against him/her, as an example of small children, the elderly, and women, people who are physically or mentally. In this type, those accountable were public and the government, because it is not able to protect helpless victims.

5) Socially weak victims are those that are not considered by the public as a member, for example, immigrants and minorities. In this type,the accountability lies on criminals and society.

6) Self-victimizing victims are those who become victims because of his/her own actions, such as drug addiction, homosexuality and gambling. In this type,the accountability lies fully on the perpetrators who are also victims.

7) Political victims are those who suffer because of their political opponents. In this type that no one can be justified.

\section{The Handling of Legal Protection for Victims of Crime:-}

Barda Nawawi Arief said that the positive criminal law in force recently the protection of victims is more as an "abstract protection" or "indirectly protection"it means various formulations of criminal offenses in the legislations during this per sethere is in abstractodirectly protection against rights and legal interests of victims. ${ }^{28}$

\footnotetext{
${ }^{26}$ Bedi Setiawan Al Fahmi. (2009). Perlindungan Korban Tindak Pidana Perkosaan Dalam Proses Peradilan Pidana Perspektif Pembaharuan Hukum Acara Pidana Indonesia. Jurnal Hukum dan Pembangunan No. 1 Vol. 16 Januari 2009. Page. 65

${ }^{27}$ Rena Yulia. (2011). Viktimologi: Perlindungan Hukum Terhadap Korban Kejahatan. hlm 164-165. Jurnal Intelek Volume 7 No. 3 Desember 2011. Page. 54

${ }^{28}$ Barda Nawawi Arief. (2001). Masalah Penegakan Hukum Dan Kebijakan Hukum Pidana dalam Penanggulangan Kejahatan. Citra Aditya Bakti : Bandung. Page. 56
} 
Article 1 point 6 of Act No. 13 of 2006 on Witness and Victim Protection as amended by Act No. 31 of 2014 on the Amendment of Act No. 13 of 2006 on Witnesses and Victims Protection, confirmed that the protection is all effort rights fulfillment and the provision of assistance to provide security to witnesses and/victim that must be implemented the Agency of Witness and Victim Protection or other Institutions in accordance with the provisions of this Act. The sense of victims protection can be seen into 2 (two), namely:

1. As legal protection for not being a crime victim (it means the protection of Human Rights or individual legal interests).

2. As protection to obtain guarantee/legal compensation for the suffering/loss of suffered people (it is similar to the sympathetic of victim). This type that can be vindication/rehabilitation, recovery of equanimity among others with forgiveness, compensation, such as restitution, guarantees/social welfare benefits and so on.

The purpose of victim protection were providing security to victims, particularly when providing information on any criminal justice process, providing encouragement and motivation to the victim not to be afraid to undergo criminal justice process, restore the confidence of victims in social life, and a sense of fairness, not just to the victims and their families, but also to the community. ${ }^{29}$

In general, in theory there are 2 (two) models of the victim protection, namely: ${ }^{30}$

1. The procedural rights model

In France, this model is called "partie civile model" (civil action system) .In short this model emphasizes the active role of victims in the criminal justice process, such as helping the public prosecutors, involved in every level of examination of the case, shall be heard if the convict is released conditionally, and so forth. In addition, with the participation actively in the criminal justice process, victims can regain self-esteem and confidence. The involvement of the victim has a positive aspect in law enforcement, and also has a negative side because active participation of victims in the criminal justice process execution can lead to personal interests over the public interest.

The theory as background to the formation of the prosecutor institution, as stated by Jan JM van Dijk, the Hague, that "historically this has been the main justification for the establishment of the office of the public prosecutor". Furthermore, another reason put forward a group that opposes the procedural right to the victim is given the role of individual to the victim in trial process or prosecution of perpetrators, making it participate to responsible for the trial, and the results of that process so that the burden of this responsibility will be pressure heavy enough for victims in many respects. Pressure can come from a person with whom the victim made contact and/or caused by police or prosecutors who will take advantage of their rights in the public interest. Offender and his lawyer will seek to influence the behavior of victims during the process and sometimes using intimidation.

2. The services model

This model emphasizes compensation or restitution and making an effort to gain condition of traumatized victims, fear and distress as a result of crime. A policy of sentenced formulation system that oriented in the positive law of victims to come include a policy of victim protection formulation in material criminal law, a policy of victim protection formulation under formal criminal law and a policy of victim protection formulation in criminal law enforcement. The substance of positive law in question is the Draft Law on the Criminal Code Procedure of 2008 and the Draft Law on the Criminal Code Procedure of 2009.

Additional penalty in the draft law on the Criminal Code Procedure in the elucidation of Article 67 paragraph (1) is defined as "compensation payments" that may be imposed only if the judge "clearly stated in the formulation of crime". The provisions of Article 54 in the Criminal Code Procedure assert that the punishment aimed at resolving the conflict posed by crime, restoring balance, and bring a sense of peace in society." The provisions of Article 55 paragraph (1) determines that the Guidelines of Punishment must be considered judges includes the influence of criminal offenses against victims or their families; forgiveness from the victim and/ or her/his family." Explanation of the provisions of paragraph (1) contains Guidelines of Punishment were very helpful in considering the measure or judge the severity of the punishment to be imposed. Taking into account the matters specified in the guidelines is expected sentence or punishment imposed is proportionate and can be understood both by society and the convict.

\footnotetext{
${ }^{29}$ Article 4 of Act No. 13 on 2006 on Witness and Victim Protection

${ }^{30}$ Ahmad Kamil. (2012). Mediasi Penal dalam Penanganan Tindak Pidana. Mahkamah Agung Republik Indonesia : Jakarta . Page. 4
} 
The details of this provision are not limiting, meaning that the judge may add other considerations other than those listed in this paragraph (1).

The provisions of Article $71 \mathrm{c}, \mathrm{d}$ and $\mathrm{g}$ specifies that "by keeping into account Article 54 and 55, imprisonment may be imposed so far, if encountered the following circumstances: 1. loss and suffering of victims is not too big; 2 . the defendant has paid compensation to victims of crime victims; 3. Victim of crime encourage the occurrence of criminal offense." Elucidation of Article 71 confirms that the provisions of Article 71 are intended to assist the judge in determining the penal measure to be imposed.

Article 54 and 55 provides guidelines for the judge can convict proportionately and effectively and the provisions of Article 71 of this as a rule of sentencing for the judge in the case will not impose imprisonment in conditions that are described in Article 71. Formulation of the provisions of Article 77 is not operational because there are "provisions of the criminal types that can be imposed judge" after he did not impose imprisonment. Such provisions are also not listed in the explanation. The provisions of Article 65 paragraph (1) under the paragraph "types of criminal" in addition to prison, also listed as principal criminal, namely; closing, supervision, fines and community work. The problem is if the provisions of Article 71 are met, what type of punishment can be imposed judge to determine criminal dose to be imposed proportionate and effective.

The compensation or restitution to victims of crime has been adopted by other countries, especially the Anglo-Saxon legal systems. New Zealand is one of the countries that recognize compensation to victims in a legal setting. In New Zealand, the compensation of victims has been approved as a type of punishment in its legislation. This is motivated by the view that in terms of the nature of suffering or material losses suffered by the victim as a result of criminal acts committed by others, it is only fair perpetrators of criminal acts (the other person) who provide compensation. ${ }^{31}$

Another example is in Japan. Rationale and culture of the Japanese people against the Constitution is not contrary to the ideology that is universal, but rather relied on the ideology of the special (particular), because in this way, Japan can suppress the crime rates into the lowest in the world. Law enforcement practices in Japan prefer an agreement or consensus as compared with the settlement via litigation. ${ }^{32}$

\section{Restorative Justice:-}

Restorative justice is a concept that responded the development of the criminal justice system by focusing on the needs of victims and community involvement that feels marginalized by mechanisms that work in the criminal justice system that exists today. ${ }^{33}$ Muladi argued his view that in restorative justice, the position of case must be changed, no longer in the interest of order, but for the sake of victims and the recovery of material and psychological. The point is how to prevent offenders from imprisonment, but remain responsible.

Van Ness suggested that restorative justice is a theory of justice that promotes the recovery of losses due to malicious behavior, in which the complete recovery through a process of inclusive and cooperative. If viewed from the recovery of various conflicts, the essential elements of the definition of restorative justice by some experts is more priority to reconciliation or improvement efforts between the perpetrator, the victim, and the community rather than retaliation. ${ }^{34}$

Restorative justice is a fair solution that involved offenders, victims, their families and other relevant parties in a criminal act jointly seek solutions to the offense and its implications by emphasizing restoration to the original condition

Restorative Justice is a concept of punishment, but as a concept of punishment is not confined to criminal law provisions (formal and material). It also must be observed in terms of criminology and the prison system. From the

\footnotetext{
${ }^{31}$ Roeslan Saleh. (1984). Segi Lain Hukum Pidana. Ghalia Indonesia : Jakarta. Page. 21.

${ }^{32}$ Romli Atmasasmita. (2001). Masalah Santunan Terhadap Korban Tindak Pidana," Majalah Hukum Nasional Departemen Kehakiman. 1992. Pages 44-45

${ }^{33}$ Eva Achjani Zulfa. 2010. Pergeseran Paradigma Pemidanaan. Lubuk Agung : Bandung. Page. 65

${ }^{34}$ Ibid
} 
facts, the applicable criminal system does not guarantee integrated justice, namely justice for perpetrators, justice for victim, and justice for the people. This has encouraged the concept of "Restorative Justice." "35

Bagir Manan argued that restorative justice contains principles, such as build participation together between the offender, victim and community groups to resolve an incident or crime, putting perpetrators, victims, and the community as "stakeholders" working together and immediately tried to find a solution which is perceived to be fair to all parties (win-win solutions)., 36

Restorative justice approach offers different views and approaches in understanding and dealing with a criminal offense, as depicted on the definition put forward by Dignan, as follows:

Restorative justice is a new framework for responding to wrong doing and conflict that is rapidly gaining acceptance and support by edsucational, legal, social work, and counceling professionals and community groups. Restorative justice is a valued-based approach to responding to wrongdoing and conflict, with a balanced focus on the person harmed, the person causing the harm, and the affected community.

The definition requires a certain condition that puts restorative justice as a fundamental value that used in response to a criminal offense. In this case, the focus of attention required balance between the interests of offenders and victims and take into account the impact of the settlement of the criminal cases in the community.

The goal of restorative justice is to encourage the creation of a fair judicial and encourage the parties to participate therein. Victims feel that their sufferings are cared and compensation agreed balanced by suffering and loss suffered. The main objective is to empower the victim restorative justice, where offenders are encouraged to pay attention to recovery.

Restorative justice attaches great importance to the fulfillment of material, emotional, and social victim. The success of restorative justice, as measured by the large of loss has been recovered by offender, not measured by how sentence imposed by the judges. Its essence, as far as possible the perpetrator is removed from the criminal proceedings and prison. But, as said by Kent Roach, restorative justice is not only provides an alternative to prosecution and imprisonment, but also ask the responsibility of the perpetrators. Criminal acts in restorative justice are interpreted as a violation of the law and the state, besides facing the perpetrator is the victim and the community, not the government.

The process for resolve disputes, restorative justice is no longer use conventional methods that have been used in the criminal justice system, which only focuses on finding who is right and who is wrong, and to find what is appropriate punishment given to the guilty party. While in resolve disputes through restorative justice are no longer either case, desired by restorative justice is a restoration of the offender so that he will no longer commit crimes, the recovery also helped addressed to the victim as an injured party and the relationship between the victim, the offender and society to the course life can return to normal.

The theory of punishment recognizes a system derived from the conception of individualization of criminal and known as the double track system. This system introduces two penalties together that are criminal and action sanctions. This system puts the two in parallel and equal. Both equality are based on the premise that element of suffering through criminal sanctions and the elements of imprisonment through action sanction is two things that are equally important.

These linkage is described by Gerber and Mc Anany argued that criminal sanctions or retributive is not fully removed in sentencing because under certain conditions despite the implementation of sanctions moving towards rehabilitation as goal fully but still there should be criminal prosecution and instead sanctions only relying on criminal sanctions (retributive) proved ineffective to restore social and moral qualities of a criminal in order to

\footnotetext{
${ }^{35}$ Joint Decree between the Chairman of the Supreme Court, the Attorney General of the Republic of Indonesia, the Head of the Indonesian National Police, Minister of Justice and Human Rights of the Republic of Indonesia, Minister of Social Affairs of the Republic of Indonesia and the Minister of Women Empowerment and Child Protection of the Republic of Indonesia.

${ }^{36}$ Lies Sulistiani. (2010). Perlindungan Saksi dan Korban di Indonesia. Press Release No.02/LPSK/PR/II/2010. Lembaga Perlindungan Saksi Republik Indonesia : Jakarta. Page. 4
} 
integrate more with the community. This is the reason for the need to integrate between criminal and action sanctions. $^{37}$

Double track system requires the element of suffering and imprisonment are equally accommodated in the system of criminal law sanctions. This view was expressed also by Albert Camus, ${ }^{38}$ who stated that the application of criminal sanctions there needs to be equality between punishment and treatment. Punishment is a logical consequence of freedom is misused by offenders but on the other hand a perpetrator remains of a man who has the right to reach the new values and new adjustments in order to be a good human being.

Hart $^{39}$ argued that a theory of punishment that is morally acceptable is able to demonstrate the complexity of the prosecution and described it as a compromise between different principles and contradictory that any punishment is complex. Complexity is expressed by Hart according to the author showed that the punishment in view of Hart combines the suffering sanctions and for imprisonment.Arief ${ }^{40}$ said that the fundamental difference between criminal sanctions and action sanctions is the criminal question questioned why the imprisonment is held while the action sanctions questioned to what the imprisonment is held. Criminal sanctions are reactive to an act, while action sanctions are anticipatory against the perpetrators of such acts. The focus of criminal sanction is perpetrators act through an affliction to deter while the focus of criminal sanctions is to give assistance for change.

J.E. Jonkers also argued that criminal sanctions emphasized for crimes committed while action sanctions focused on goals that are social. ${ }^{41}$ Description and views on criminal sanctions and action sanctions indicate that criminal sanctions oriented to sanctions for action, while the action sanctions oriented to the community protection. The debate of philosophy and theory of punishment always have ups and downs in its development, which leads to the emergence of new strategies in sentencing, as follows:

a) Indeterminate sentence

Indeterminate sentence is a strategy of criminal sanction that provides flexibility to judges in sentencing. The development of this strategy gained sharp criticism because they provide greater uncertainty than benefits. The uniformity for any criminal offense generates inequality in the process of criminal prosecution.

b) Just desert model

Just desert model is a strategy that is based on fairness with regard punishment as prevention and retribution.Prevention aimed at preventing a perpetrator to repeat offense or crime in later while retributionaimed to provide vengeance for a criminal offense committed.

c) Restorative model

Restorative model is a model of punishment that proposed by the abolitionists. This model is often confronted with retributive models.

\section{Conclusion:-}

The essence of legal protection for crime victims in the handling of conventional crime in Indonesia is not yet optimal to take attention and gives legal protection to conventional crime victim in achieving fairness, expediency and legal certainty as a legal purpose. Conventional crime victims are an integral part of a legal system, which received less attention in obtaining their rights in the criminal justice system in Indonesia.Legal protection of conventional crime victim in Indonesia has been set in legislations, but it is not optimal because the mostly of legislation is more focused of legal protection to the perpetrators rather than the victims. As a result, the implementation of legal protection for conventional crime victim is not optimal, so it is very important the understanding of community, the victim and also law enforcement officers in the implementation of rules and mechanisms of legal protection against conventional crime victims to get their rights.

The implementations of restoration justice in the framework of legal protection for conventional crime victim were by carrying out penal mediation to compensate the conventional crime victims. However, the compensation does not mean that criminal elements were done then be lost. The compensation will only relieve the perpetrators. Therefore, the concept of restorative justice cannot be implemented purely without a retributive justice, it means that the

\footnotetext{
${ }^{37}$ Sholehuddin. (2010). Sistem Sanksi Dalam Hukum Pidana. PT RajaGrafindo : Jakarta. Page 54

${ }^{38}$ Ibid.

${ }^{39}$ Ibid. Page. 56

${ }^{40}$ Barda Nawawi Arief. 2002. Perbandingan Hukum Pidana. RajaGrafindoPersada : Jakarta Page. 51

${ }^{41}$ Ibid
} 
compensation to victims did not causes the offender was not convicted. Currently, the direction of sentencing is in restorative justice models with not negate retributive justice model in which called as a balance perspective sentencing that is a balance between the interests of offenders, victims and communities or called as criminal prosecution balance perspective.

\section{References:-}

1. Ahmad Kamil. (2012). Mediasi Penal dalam Penanganan Tindak Pidana. Mahkamah Agung Republik Indonesia: Jakarta.

2. Anshari Dimyati.(2013). Kebijakan Perlindungan Hukum Terhadap Saksi dan Korban. Tesis. Universitas Diponegoro : Semarang.

3. Bambang Sunggono. (1991). Metode Penelitian Hukum. PT RajaGrafindo Persada. Jakarta.

4. Barda Nawawi Arief. (2001). Masalah Penegakan Hukum Dan Kebijakan Hukum Pidana dalam Penanggulangan Kejahatan. Citra Aditya Bakti : Bandung.

5. Barda Nawawi Arief. (2002). Perbandingan Hukum Pidana. RajaGrafindoPersada : Jakarta.

6. Bedi Setiawan Al Fahmi. (2009). Perlindungan Korban Tindak Pidana Perkosaan Dalam Proses Peradilan Pidana Perspektif Pembaharuan Hukum Acara Pidana Indonesia. Jurnal Hukum dan Pembangunan No. 1 Vol. 16, 2009.

7. Budiyanto. (2000). Dasar-dasar Ilmu TataNegara. Erlangga : Jakarta.

8. Eva Achjani Zulfa. 2010. Pergeseran Paradigma Pemidanaan. Lubuk Agung : Bandung.

9. H.W.R Wade. (1970). Administrative Law. Third Edition. Clarendon Prees : Oxford University.

10. Hamid A. Attamimi. (1990). Peranan Keputusan Presiden RI Dalam Penyelenggaraan Pemerintahan Negara. Dissertation. Graduate School Universitas Indonesia : Jakarta.

11. Ira Dwiati. (2007). Perlindungan Hukum Terhadap Korban Tindak Pidana Perkosaan Dalam Peradilan Pidana. Thesis. Universitas Diponegoro : Semarang.

12. J.C.T. Simorangkir and Woerjono Sastropranoto.(1959). Hukum Indonesia. Gunung Agung: Jakarta.

13. Lies Sulistiani. (2010). Perlindungan Saksi dan Korban di Indonesia. Press Release No.02/LPSK/PR/II/2010. Lembaga Perlindungan Saksi Republik Indonesia: Jakarta.

14. Mochtar Kusumaatmadja. (2003). Pengantar Hukum Indonesia. PT. Alumni: Bandung.

15. Muhadar et al. (2010). Perlindungan Saksi dan Korban dalam Sistem Peradilan Pidana. Putera Media Nusantara: Surabaya.

16. Muhammad Tahir Azhary. 1995. Negara Hukum Indonesia Analisis Yuridis Normatif Tentang Unsur-Unsurnya.UI-Press. Jakarta

17. Munir Fuady. (2009). Negara Hukum dan Demorasi. Kencana Prenada Group: Jakarta.

18. Mushammad Asrun. (2001). Krisis Peradilan Mahkamah Agung di bawah Soeharto.ELSAM. Lemabaga Studi dan Advokasi Masyarakat : Jakarta.

19. Philipus M. Hadjon. $\left({ }^{1987}\right)$. Perlindungan Hukum Bagi Rakyat Indonesia Sebuah Study Prinsip-prinsipnya, Penanganannya oleh Pengadilan dalam Lingkungan Peradilan Umum dan Pembentukan Peradilan Administrasi Negara, PT. Bina Ilmu : Surabaya.

20. Poerwadarminta. Kamus Bahasa Indonesia. Balai Pustaka : Jakarta.

21. Rena Yulia. (2011). Viktimologi: Perlindungan Hukum Terhadap Korban Kejahatan. hlm 164-165. Jurnal Intelek Volume 7 No. 3, 2011.

22. Ridwan, H.R. (2007). Hukum Administrasi Negara. PT RajaGrafindo : Jakarta.

23. Roeslan Saleh. (1984). Segi Lain Hukum Pidana. Ghalia Indonesia: Jakarta.

24. Romli Atmasasmita. (2001). Masalah Santunan Terhadap Korban Tindak Pidana,” Majalah Hukum Nasional Departemen Kehakiman. 1992. Pages 44-45

25. Sholehuddin. (2010). Sistem Sanksi Dalam Hukum Pidana. PT RajaGrafindo : Jakarta.

26. Soeroso. (2006). Pengantar Ilmu Hukum. Sinar Grafika: Jakarta.

27. Sujoko. (2008). Implementasi Tuntutan Ganti Kerugian Dalam Pasal 98 KUHAP Terhadap Tindak Pidana Pemerkosaan di Wilayah Hukum Semarang. Universitas Diponegoro: Semarang.

28. United Nation Declaration of Basic Principles of Justice for Victims of Crime and Abuseof Power 29 November 1985. 